\title{
PERLINDUNGAN HUKUM PEMEGANG HAK CIPTA LAGU DAN MUSIK DI ERA DIGITAL
}

Surung B Simanjuntak, Bernard Nainggolan, Hendri Jayadi

Fakultas Hukum Universitas Kristen Indonesia, Jakata, Indoensia

Email: surungbs@gmail.com, bernard.nainggolan@yahoo.com,drhendrijayadi@gmail.com

\begin{tabular}{|c|c|}
\hline INFO ARTIKEL & ABSTRAK \\
\hline $\begin{array}{l}\text { Diterima } \\
12 \text { November } 2021 \\
\text { Direvisi } \\
\text { 15 November } 2021 \\
\text { Disetujui } \\
\text { 20 Januari } 2022 \\
\text { Kata Kunci: } \\
\text { Perlindungan } \\
\text { Hukum, Pemegang } \\
\text { Hak Cipta, Music, } \\
\text { Era Digital. }\end{array}$ & $\begin{array}{l}\text { Penelitian ini dilatarbelakangi oleh maraknya eksploitasi penggunaan } \\
\text { aplikasi youtube dan facebook sehingga marak pula eksploitasi karya } \\
\text { musik yang terjadi dengan tidak sepengetahuan oleh pencipta atau } \\
\text { pemegang hak ciptanya. Hal ini lah yang menjadi pengaruh negatif dari } \\
\text { teknologi ini sehingga dapat menghilangkan hak-hak ekonomi dari para } \\
\text { pencipta dan pemegang hak cipta. Bentuk penelitian yang dilakukan } \\
\text { dalam tulisan ini adalah bentuk penelitian diagnostik, artinya metode } \\
\text { penelitian diagnostik merupakan metode penelitian yang dirancang } \\
\text { dengan menuntun seorang peneliti ke arah suatu tindakan, sehingga } \\
\text { dengan metode penelitian ini peneliti akan di arahkan pada sebab-sebab } \\
\text { timbulnya suatu gejala. Hasil penelitian ini Secara khusus pelindungan } \\
\text { yang dibutuhkan oleh para insan seni dan dalam dunia industri musik ini } \\
\text { adalah pelindungan terhadap hak ekonomi dan pelindungan terhadap hak } \\
\text { moral. Adanya kesenjangan ekonomi yang terlihat di dunia industri } \\
\text { musik ini terhadap para pencipta lagu sebagai pemegang hak cipta lagu } \\
\text { dibandingkan dengan ketenaran lagu yang diciptakan, yang artinya lagu } \\
\text { yang diciptakannya sangat diminati oleh masyarakat dan diputar atau } \\
\text { diperdengarkan di berbagai tempat secara berulang-ulang. Jika suatu } \\
\text { karya cipta di katakan adalah sebuah kekakayan yang berkaitan dengan } \\
\text { ekonomi, sebagian besar penggunaan lagu atau musik tersebut selalu } \\
\text { disertakan dengan aktivitas ekonomi (Nainggolan, 2016). Seharusnya } \\
\text { para pencipta lagu dapat menikmati kekayaan intelektualnya yang mana } \\
\text { objek kekayaan intelektual (lagu/musik) tersebut begitu disenangi oleh } \\
\text { masyarakat lain. Hak Kekayaan Intelektual adalah hak untuk menikmati } \\
\text { secara ekonomis hasil dari suatu kreativitas intelektual, dimana objek } \\
\text { yang diatur dalam HKI adalah karya-karya yang timbul atau lahir karena } \\
\text { kemampuan intelektual manusia. }\end{array}$ \\
\hline
\end{tabular}

\section{ABSTRACT}

This research is motivated by the rampant exploitation of the use of youtube and facebook applications so that the rampant exploitation of music works that occur without knowledge by the creator or copyright holder. This is the negative influence of this technology so that it can remove the economic rights of creators and copyright holders. The form of research carried out in this paper is a form of diagnostic research, meaning that diagnostic research methods are research methods designed by guiding a researcher towards an action, so that with this research method researchers will be directed at the causes of the onset of a symptom. In particular, the protection needed by art people and in the world of the music industry is protection of economic rights and

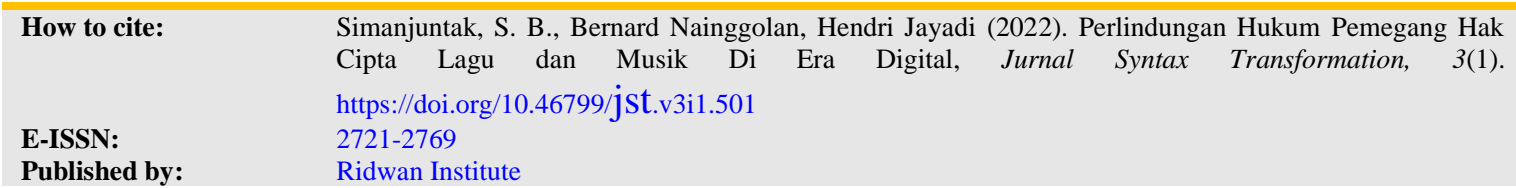




\begin{tabular}{ll}
\hline & $\begin{array}{l}\text { protection of moral rights. There is an economic gap seen in the world } \\
\text { of the music industry against songwriters as song copyright holders } \\
\text { compared to the fame of songs created, which means that the songs they } \\
\text { create are in high demand by the public and played or listened to in } \\
\text { various places over and over again. If a copyrighted work is said to be a } \\
\text { related to the economy, most of the use of the song or music is always } \\
\text { accompanied by economic activity (Nainggolan, 2016). The songwriters } \\
\text { should be able to enjoy their intellectual property which the object of } \\
\text { Keywords: } \\
\text { Legal Protection, } \\
\text { Copyright Holdectual property (song / music) is so favored by other people. } \\
\text { Music, The Digital } \\
\text { Age }\end{array} \quad \begin{array}{l}\text { Intellectual Property Rights are the right to enjoy economically the } \\
\text { IPR are works that arise or are born due to human intellectual ability. }\end{array}$ \\
\hline
\end{tabular}

\section{Pendahuluan}

Berbicara mengenai era digital atau digitalisasi dalam dunia industri musik, maka ada dua hal yang menjadi objek sasarannya, yang pertama adalah digitalisasi dalam proses produksi dan yang kedua adalah digitalisasi dalam proses pemasarannya. Digitalisasi dalam proses produksi suatu karya cipta lagu dan musik maksudnya adalah penggunaan teknologi digitalisasi dalam proses produksi karya musik (fiksasi) yang mana hal tersebut tentunya memberikan kemudahan-kemudahan dalam aspek proses produksinya. Teknologi digital atau sistem digitalisasi yang digunakan ini dapat melakukan percepatan waktu produksi, peningkatan kualitas produks dan penghematan biaya produksi (cost of production).

Yang kedua adalah digitalisasi dalam proses pemasaran, dimana karya-karya musik dipasarkan tidak lagi dengan sistem konvensional atau penjualan hasil karya musik tersebut tidak lagi dijual dalam bentuk CD, VCD, DVD dan diedarkan melalui toko-toko kaset atau VCD yang ada, namun saat ini para pelaku industri musik telah melakukan hal tersebut melalui teknologi digital yang saat ini cukup pesat perkembangannya. Pemasaran atau publising yang digunakan adalah dengan memanfaatkan teknologi digital melalui media-media atau aplikasi-aplikasi (Platform) yang tersedia dan terhubung dengan jaringan internet.
Pada tahun 1995 Fraunhofer institute jerman melalui tim mereka telah berhasil menciptakan pemutaran musik versi windows yang dapat memecahkan algoritma MP3 sehingga dapat dinikmati oleh konsumen secara realtime dan wimplay inilah yang menjadi cikal bakal media player yang terdapat dalam personal computer (Ahmad Tamamy, 2009). Saat ini proses pemasaran karya cipta tidak lagi dilakukan dengan cara penjualan dalam bentuk fisik seperti kaset, compact disc, namun saat ini penjualan hasil produksi rekaman musik telah dilakukan melalui media internet (digital) dalam bentuk suara (audio) saja atau dalam bentuk suara dan gambar (audio-visual).

Prinsip deklaratif sesuai apa yang diamanahkan oleh undang-undang no 28 tahun 2014 tentang hak cipta yang dilakukan melalui pemanfaatan teknologi digital ini tentunya terkait juga dengan deklarasi hak moral pencipta serta disisi lain berpotensi untuk mendapatkan penambahan ekonomi dari hasil karya ciptanya. Dengan semakin banyaknya platform (online) yang dapat dimanfaatkan oleh para pelaku industri musik ini tentunya akan menaikkan intensitas penayangan (viewers) karya musik tersebut dan akan semakin berpotensi untuk menambah pendapatan income dari pemegang hak cipta tersebut disamping royalti-royalti yang didapatkan melalui pagelaran secara offline. 
Teknologi yang baru yang disebut dengan sistem digitalisasi tentunya mempunyai manfaat yang banyak, namun juga harus disadari bahwa teknologi digitalisai ini juga mempunyai sisi-sisi yang negatif dalam hal-hal tertentu. Penambahan-penambahan fasilitas (up-grade) kemampuan aplikasi yang digunakan oleh para pelaku industri musik tadi sebagai platform juga telah dimanfaatkan oleh para masyarakat luas dalam bentuk yang sama, namun sayangnya masyarakat tersebut memanfaatkan platform tersebut dengan kebanyakan memakai karya-karya musik para pencipta lagu, dan bukan memakai karya ciptanya sendiri, sehingga disini banyak ditemukan plagiat karya musik yang tentunya merugikan pencipta lagu sebagai pemegang hak eksklusif. Publikasi karya musik melalui teknologi digital ini sangat mudah dan gampang dilakukan oleh orang lain tanpa adanya izin dari pemegang hak ciptanya.

Aplikasi sebagai platform terutama aplikasi youtube telah dengan konsisten memberikan penghargaan (reward) dalam bentuk materi atas konten yang dikelola dan ter-monetizing kepada para pemilik account youtube. Hal ini lah yang dimanfaatkan oleh masyarakat dunia dan di Indonesia berlombalomba membuat konten yang menarik dan banyak sehingga berpotensi mendatangkan penonton (viewers) yang banyak dan jumlah waktu penayangan yang lebih lama. Topik dari sajian-sajian tontonan yang masyarakat buat sangat bermacam-macam, ada yang membuat topik atau konten dengan bentuk wawancara, ada dalam bentuk kuliner, liputan tentang perjalanan ke suatu tempat, dan ada yang menyajikan konten lagu-lagu atau musik dan lain sebagainya.

Hak cipta adalah hak eksklusif (Wibawa \& Krisnawati, 2019) pencipta yang timbul secara otomatis berdasarkan prinsip deklaratif setelah suatu ciptaan diwujudkan dalam bentuk nyata tanpa mengurangi pembatasan sesuai dengan ketentuan peraturan perundang-undangan kalimat diatas adalah rumusan Undangundang nomor 28 tahun 2014 tentang hak cipta pasal 1 ayat (1) yang mana dijelaskan bahwa pemegang hak cipta mempunyai hak eksklusif yang tidak dapat diganggu oleh orang lain sehingga setiap adanya pengumuman (Besar, 2012) harus dengan seizin dari pemegang hak cipta.

Dengan semakin maraknya penggunaan aplikasi youtube dan facebook sehingga marak pula eksploitasi karya musik yang terjadi dengan tidak sepengetahuan oleh pencipta atau pemegang hak ciptanya. Hal ini lah yang menjadi pengaruh negatif dari teknologi ini sehingga dapat menghilangkan hak-hak ekonomi dari para pencipta dan pemegang hak cipta.

Penelitian ini dikuatkan dengan penelitian sebelumnya yang dilakukan oleh (Salindeho, 2017) dengan judul "Perlindungan Musik Dan Lagu Di Era Teknologi Internet Dalam Perspektif Undang-Undang Hak Cipta Indonesia." Dengan hasil penelitian diungkapkan bahwasanya Terhadap pelanggaran hak moral dan hak ekonomi pencipta lagu dan musik dapat dikenakan sanksi pidana berdasarkan Pasal 113. 2. Kemajuan teknologi membuat orang mudah melakukan pelanggaran/pembajakan karya cipta musik dan lagu di era digital melalui teknologi dowmloud music. Faktor ekonomi serta lemahnya pemahaman masyarakat terhadap undang-undang hak cipta mempermudah pihak-pihak tertentu untuk mencari keuntungan dengan melakukan pembajakan atas karya cipta music.

\section{Metode Penelitian}

Penelitian hukum adalah merupakan suatu kegiatan ilmiah, yang didasarkan pada metode, sistematika dan pemikiran tertentu, yang bertujuan untuk mempelajari satu atau beberapa gejala hukum tertentu, dengan jalan menganalisanya. Penelitian yang digunakan dalam tesis ini adalah dengan menggunakan dua tipe penelitian, yang pertama adalah 
penelitian hukum normatif/doktrinal (normative legal research) dan yang kedua adalah penelitian hukum empiris / nondoktrinnal (empirical legal research). penelitian hukum normatif/doktrinal (normative legal research) bertujuan untuk mengidentifikasi, mengkaji dan menganalisis berbagai data sekunder seperti, perundangundangan, keputusan pengadilan, teori hukum dan pendapat para sarjana hukum. Bentuk penelitian yang dilakukan dalam tulisan ini adalah bentuk penelitian diagnostik, artinya metode penelitian diagnostik merupakan metode penelitian yang dirancang dengan menuntun seorang peneliti ke arah suatu tindakan, sehingga dengan metode penelitian ini peneliti akan diarahkan pada sebab-sebab timbulnya suatu gejala.

\section{Hasil dan Pembahasan}

\section{A. Pelindungan Hukum terhadap Pencipta}

\section{Lagu Dan Musik}

Pasal 28A Undang-undang Dasar 1945 menegaskan bahwa setiap orang berhak untuk hidup serta berhak mempertahankan hidup dan kehidupannya. Kemudian pasal 28C semakin tajam merumuskan tentang pelindungan hukum kepada anggota masyarakat bahwa setiap orang berhak mengembangkan diri melalui pemenuhan kebutuhan dasarnya, berhak mendapatkan pendidikan dan memperoleh manfaat dari ilmu pengetahuan dan teknologi, seni dan budaya, demi meningkatkan kualitas hidupnya dan demi kesejahteraan umat manusia.

Hak cipta merupakan kekayaan intelektual dalam bidang ilmu pengetahuan, seni dan sastra yang bernilai ekonomis dan mempunyai peranan strategis dalam mendukung pembangunan bangsa serta memajukan kesejahteraan umum sebagaimana diamanatkan oleh Undang-Undang Dasar Republik Indonesia tahun 1945 (Republik Indonesia, 2014). Undangundang nomor 28 tahun 2014 tentang hak cipta yang secara resmi berlaku mulai pada tanggal 16 Oktober 2014. Dalam undang-undang ini pemegang hak cipta lagu dan musik adalah sebagai salah satu objek penting dan utama dalam hal pelindungan yang direncanakan.

Upaya pemerintah untuk selalu meng-upgrade aturan hukum tentang hak cipta agar tetap sejalan dengan perkembangan zaman telah diakomodasikan dalam undang-undang nomor 28 tahun 2014 tentang hak cipta ini, sehingga beberapa rumusan tentang pelindungan pencipta, pemegang hak cipta lagu maupun pemegang hak cipta musik, bahkan pemilik hak terkait secara garis besar adalah sebagai berikut (Republik Indonesia, 2014) :

a.Pelindungan hak cipta dilakukan dengan waktu lebih panjang sejalan dengan penerapan aturan di berbagai negara sehingga jangka waktu pelindungan hak cipta di bidang tertentu diberlakukan selama hidup pencipta ditambah 70 (tujuh puluh) tahun setelah pencipta meninggal.

b. Pelindungan yang lebih baik terhadap hak ekonomi para pencipta dan/atau pemilik hak terkait, termasuk membatasi pengalihan hak ekonomi dalam bentuk jual putus (sold flat)

c.Penyelesaian sengketa secara efektif melalui proses mediasi, arbitrase atau pengadilan, serta penerapan delik aduan untuk tuntutan pidana.

d. Pengelola tempat perdagangan bertanggung jawab atas tempat penjualan dan/atau pelanggaran hak cipta dan/atau hak terkait di pusat tempat perbelanjaan yang dikelolanya. 
e.Hak cipta sebagai benda bergerak tidak berwujud dapat dijadikan objek fidusia.

f. Menteri diberikan kewenangan untuk menghapus ciptaan yang sudah dicatatkan, apabila ciptaan tersebut melanggar norma agama, norma susila, ketertiban umum, pertahanan dan keamanan negara serta ketentuan perundang-undangan.

g. Pencipta, pemegang hak cipta, pemilik hak terkait menjadi anggota Lembaga Manajemen Kolektif agar dapat menarik imbalan royalti.

h. Pencipta dan/atau pemilik hak terkait mendapat imbalan royalti untuk ciptaan atau produk hak terkait yang dibuat dalam hubungan dinas dan digunakan secara komersial.

i. Lembaga Manajemen Kolektif yang berfungsi menghimpun dan mengelola hak ekonomi pencipta dan pemilik hak terkait wajib mengajukan permohonan izin operasional kepada menteri.

j. Penggunaan hak cipta dan hak terkait dalam sarana multimedia untuk merespon perkembangan teknologi informasi dan komunikasi.

\section{Pelindungan Hukum Terhadap Pemegang Hak Cipta Lagu dan Musik Di Era Digital.}

Era digital dimulai dari revolusi industrialisasi dunia yang berkembang, era industrialisasi telah ditandai dengan empat (4) zaman industrialisasi yang tentunya sangat berpengaruh terhadap berbagai sisi kehidupan manusia di seluruh dunia yaitu (Fonna, 2019) :

a.Revolusi industri 1.0 di awal era industrialisasi dan mekanisasi, inovasi di sektor industri tekstil mengalami perkembangan yang luar biasa. Hal ini di awali dengan pembuatan mekanisasi mesin pintal. Mesin pintal merupakan temuan inovasi yang mengubah corak sektor industri tekstil. Produksi tekstil yang sebelumnya menggunakan tenaga manusia berubah menggunakan tenaga mesin yang tentu bisa lebih efisien dan efektif. Produktivitas produksi tekstil mengalami peningkatan berlipat-lipat. Tumpuan industri tekstil yang semula menggunakan tenaga manusia berubah menjadi tenaga mesin

b. Revolusi Industri 2.0 dikenal juga dengan revolusi teknologi dimana dalam periode ini terjadi lompatan besar dan radikal dalam perkembangan teknologi dan budaya masyarakat. Inovasi pada periode ini merupakan pengembangan industri sebelumnya dengan berbasis ilmu pengetahuan dan teknologi dan berlangsung sekitar tahun 1900-1960 yang bercirikan dengan ditemukannya mekanisasi sistem produksi massal dengan menggunakan jalur perakitan yang lebih efektif dan efisien, serta adanya standarisasi mutu dan kualitas.

c.Revolusi industri 3.0 perkembangan jaman mendorong kita untuk melakukan inovasi. Di mulai dengan Revolusi industri 1.0 yang ditandai dengan ditemukannya mesin untuk industri, revolusi industri 2.0 ditandai dengan penemuan teknologi listrik untuk industri dan berikutnya revolusi industri ke-3 yang di awali dengan munculnya teknologi informasi dan elektronik yang masuk ke dalam dunia industri yaitu sistem otomatisasi berbasis komputer dan robot. Peralatan industri sudah tidak lagi dikendalikan oleh manusia, namun sudah dikendalikan oleh komputer atau lebih dikenal dengan istilah komputerisasi. 
d. Revolusi industri 4.0 tibalah saatnya kita memasuki revolusi industri 4.0 yaitu era yang ditandai dengan adanya konektivitas manusia, data, dan mesin dalam bentuk virtual atau dikenal dengan istilah cyber physical. Perkembangan revolusi industri membawa perubahan yang sangat cepat dengan tujuan mulia menciptakan kualitas kehidupan yang lebih baik. Pada era industri 4.0 ini ada pergeseran trend inovasi ke arah teknologi digital.

Sistem pemasaran adalah sistem yang dipergunakan oleh para pemegang hak cipta lagu dan musik untuk mendapatkan hasil ekonomi dalam bentuk materi dari pemanfaatan komersial hasil karya cipta mereka, yang pertama adalah dengan mendaftarkan diri masing-masing ke Lembaga Manajemen Kolektif (LMK) yang telah mendapatkan pengesahan operasional dari menteri hukum dan hak asasi manusia (menkumham). Lembaga manajemen ini adalah lembaga nirlaba yang dibentuk dan yang dikelompokkan sesuai dengan profesi seniman misalnya adalah penyanyi dikelompokkan kedalam satu lembaga manajemen kolektif khusus penyanyi, kemudian pencipta membentuk lembaga manajemen kolektif khusus pencipta, begitu juga dengan produser fonogram dan yang tergolong sebagai musisi.

Pengelompokan pemegang hak cipta baik dalam bentuk cipta lagu atau musik yang sudah direkam dan dipublikasikan kepada publik, maka kita akan mendapati pemegang hak sebagai berikut (Nainggolan, 2016) :

1. Pencipta lagu - memiliki hak moral dan hak ekonomi atas ciptaan lagu (lagu terdiri ata : lirik, melodi dengan atau tanpa notasi)
2. Penyanyi - salah satu pemilik hak terkait disebut sebagai pelaku, memiliki hak moral dan ekonomi;

3. Produser fonogram atau produser rekaman suara - salah satu pemilik hak terkait, memiliki hak ekonomi atas produk rekaman suara.

Lembaga manajemen yang mengurusi kepentingan tertentu dalam operasionalnya akan menerima limpahan dana dari Lembaga Manajemen Kolektif Nasional yang di bentuk oleh negara yang secara langsung berhak menarik lisensi dari hasil karya musik tersebut kepada para orang-orang atau badan hukum yang telah manfaatkan hasil karya musik tersebut sesuai dengan aturan hukum yang berlaku. Beberapa pengguna hak cipta sesuai aturan perundang-undangan wajib menyetorkan royalti atas pemanfaatan hasil karya musik tersebut yaitu, pusat rekreasi alam terbuka dan pusat rekreasi dalam ruangan yang menggunakan tiket, rumah bernyanyi (karaoke), konser musik, supermarket, pasar swalayan, mall, toko, distro, salon kecantikan, pusat kebugaran, arena olah raga, ruang pameran, hotel dan fasilitas hotel, restoran dan kafe, pub, bar dan bistro, diskotik dan klub malam, nada tunggu telepon, bank dan kantor, gedung bioskop, pameran dan bazar, radio komersial dan non komersial dan terakhir adalah penyiaran televisi.

Dengan adanya suatu lembaga manajemen kolektif ini maka penarikan serta penyaluran royalti yang dikutip dari pengguna hak cipta user telah berjalan lebih baik dari sebelumnya dan saat ini pemegang hak cipta dan pemilik hak terkait telah dapat menikmati hak ekonominya dari karya cipta mereka.

Pada masa revolusi industri 4.0 perubahan melalui sistem digitalisasi dalam industri musik mulai diterapkan, seluruh proses produksi dalam industri musik ini serta proses pemasaran dari produk tersebut telah dilakukan melalui teknologi digitalisasi 
(Dewatara \& Agustin, 2019). Saat ini berbagai media platform yang berbasis digital telah menjanjikan keuntungan yang lumayan kepada seluruh masyarakat yang mau terlibat dan berkontribusi untuk memasukkan upload konten mereka ke aplikasi-aplikasi yang telah tersedia. Beberapa pengelola aplikasi atau situs telah menyiapkan berbagai aplikasi atau situs untuk menampung segala karya masyarakat dalam bentuk suara (audio) atau gabungan suara dan gambar (audio visual), sehingga saat ini para produser fonogram dan beberapa seniman yang masih memiliki data rekaman mereka yang lama memutuskan untuk meng-upload data tersebut atau mempublikasikan hasil karya rekaman mereka ke situs yang tadi, bahkan saat ini semua produksi baru mereka tidak lagi dicetak dalam bentuk CD (compact disc) tetapi sudah langsung di upload ke situs atau aplikasi seperti Youtube dan aplikasi-aplikasi yang dapat melakukan streaming lagu-lagu dan music (Utsman, 2014). Youtube adalah platform yang paling banyak digunakan oleh kalangan dunia industri musik untuk melakukan streaming.

Saat ini aplikasi youtube adalah aplikasi yang paling banyak di manfaatkan oleh seniman bahkan masyarakat luas yang difungsikan sebagai media atau platform untuk mempublikasikan atau mengumumkan/eksploitasi hasil video atau konten mereka yang memang dalam aplikasi youtube ini potensi untuk mendapatkan manfaat ekonomi sangat terbuka lebar sehingga meningkatkan minat masyarakat untuk membuat konten sebanyak-banyaknya yang tentunya harus memenuhi syarat dan ketentuan yang telah dibuat oleh pengelola youtube (Hanifannur, 2021). Demikian halnya dengan para musisi atau mereka-mereka yang hidup di dunia industri musik, baik sebagai pencipta lagu, produser fonogram, bahkan musisi sekalipun yang berhak secara hukum untuk mempublikasikan atau eksploitasi konten audio video yang bernuansa seni musik telah mengambil kesempatan dengan ikut meng upload hasil rekaman mereka yang baru dan bahkan hasil rekaman mereka yang lama. Kegiatan eksploitasi dapat berupa kegiatan pelaku (performer) di mana seorang penyanyi melantunkan sebuah lagu (ciptaan) musik yang direkam dalam compact disc atau kaset oleh produser rekaman untuk dijual secara umum kepada para konsumen (Damian, 1999). Hak Cipta adalah hak yang bersifat khusus, maka tidak ada orang lain yang boleh menikmati hak tersebut kecuali dengan izin dari pencipta Prinsip-prinsip Hak Cipta Ruang Lingkup Hak Cipta. Segala sesuatu usaha untuk melakukan eksploitasi terhadap suatu karya cipta, harus dengan seizin dari pencipta atau pemegang hak cipta. Pemanfaatan kecanggihan teknologi oleh masyarakat yang berpotensi ekonomi yang akhirnya mengorbankan pihak lain. Para musisi adalah korban teknologi informasi ini karena teknologi tersebut telah membuka peluang bagi masyarakat dunia untuk memanfaatkan karya musik para musisi dalam berbagai account (youtube) mereka yang dilakukan tanpa seizin dari pemilik lagu atau musiknya.

Negara tentunya perlu memperhatikan hal ini dengan serius karena secara langsung teknologi digital ini akan membunuh kehidupan industri musik yang mana industri musik ini adalah salah satu bagian dari ekonomi kreatif yang berkontribusi cukup besar terhadap kemajuan negara. Salah satu upaya pemerintah Indonesia dalam melakukan perubahan-perubahan maupun pergantian terhadap Undang-undang hak cipta ini adalah dengan meratifikasi beberapa konvensi internasional antara lain (Kariodimedjo, 2010) :

a. Persetujuan TRIPs dalam WTO yang diratifikasi menjadi undang-undang nomor 7 tahun 1994 tentang pengesahan Agreement Establishing the World Trade 
Organization yang merupakan kaidah penunjuk berlakunya konvensi Bern.

b. Berne Convention pada tanggal 7 Mei 1997 dengan Keputusan Presiden (Kepres) nomor 18 tahun 1997 dan dinotifikasikan ke WIPO pada tanggal 5 Juni 1997.

Dalam pengkajian karya tulis yang diberi judul "Pelindungan Hukum Pemegang Hak Cipta Lagu Dan Musik Di Era Digital" dengan fokus permasalahan adalah tentang "Bagaimanakah pelindungan hukum pemegang hak cipta di era digital" digunakan beberapa teori sebagai pisau analisis. Teori yang pertama adalah teori perlindungan hukum yang disampaikan oleh Gustav Radbruch dalam bukunya "einführung in die rechtswissenschaften" yang membagi 3 (tiga) yang menjadi nilai dasar dari hukum yaitu :

1. Keadilan hukum (gerectigheit);

2. Kemanfaatan hukum (zwechmatigheid atau doelmatigheid atau utility);

3. Kepastian hukum (rechtmatigheid) (Anshori, 2018).

Dan secara garis besar ketiga hal diatas adalah sebagai tujuan dari di ciptakannya suatu aturan hukum. Menurut Fitzgerald sebagaimana dikutip Satjipto Raharjo bahwa munculnya teori perlindungan hukum ini bersumber dari hukum alam atau aliran hukum alam yang dipelopori oleh Plato, Aristoteles (murid Plato) dan Zeno (pendiri aliran Stoic). Aliran hukum alam yang menyebutkan bahwa hukum bersumber dari Tuhan yang bersifat universal dan abadi, serta antara hukum dan mural tidak boleh dipisahkan.

Teori yang kedua adalah teori komponen sistem hukum sebagaimana yang telah dikemukakan oleh Lawrence $\mathrm{M}$. Friedman dalam bukunya "American Law An Introduction". Dalam teori ini Friedman mengatakan bahwa ada tiga komponen sistem hukum yaitu (Anshori, 2018) :

1. Struktur hukum (Structure of Law);

2. Substansi hukum (Subtance of Law);

3. Budaya hukum (Legal Law).
Struktur hukum adalah kerangka atau rangkanya hukum, bagian yang memberi batasan terhadap keseluruhan (Nainggolan, 2016) Struktur hukum menyangkut aparat penegak hukum yaitu : Pembuat Undangundang, penyidik, pengadilan dan berbagai badan yang diberikan wewenang untuk menegakkan hukum. Lembaga-lembaga dalam sistem hukum yang ada di Indonesia adalah lembaga Kepolisian, Kejaksaan dan Pengadilan, Penasehat hukum serta badanbadan penyelesaian sengketa diluar pengadilan. Subtansi hukum adalah semua aturan hukum atau norma hukum yang telah disahkan menjadi undang-undang sesuai ketentuan yang berlaku. Sementara budaya hukum adalah menyangkut dengan sikapsikap manusia atau anggota masyarakat termasuk dalam hal ini adalah aparat penegak hukumnya.

Didalam era digital dan sesuai dengan topik pembahasan dalam karya ilmiah ini, yang perlu diperhatikan dan menjadi fokus dalam penelitian ini adalah, apakah undangundang hak cipta yang telah di sah dan resmi digunakan oleh negara kita Indonesia telah mampu untuk memberikan pelindungan yang komprehensif terhadap seluruh insan masyarakat Indonesia yang kehidupannya bergelut dalam industri musik ini? Dan selanjutnya melalui teori Lawrence $\mathrm{M}$. Friedman dengan teori sistem hukumnya akan dikaji potensi pelindungan hukum terhadap hak moral dan ekonomi dari undang-undang hak cipta yang tentunya dalam kaitannya dengan karya cipta dan dunia indsutri musik dalam lingkup era digital melalui pengkajian melalui bidang lembaga-lembaga maupun institusi-institusi, norma-norma yang berkaitan dengan pelindungan hak moral dan hak ekonomi pencipta, serta sikap-sikap dan perasaan serta pikiran masyarakat dalam kaitannya dengan pelindungan hukum terhadap hak moral dan hak ekonomi pencipta khususnya pencipta lagu atau musik. 
Secara khusus pelindungan yang dibutuhkan oleh para insan seni dan dalam dunia industri musik ini adalah pelindungan terhadap hak ekonomi dan pelindungan terhadap hak moral. Adanya kesenjangan ekonomi yang terlihat didunia industri musik ini terhadap para pencipta lagu sebagai pemegang hak cipta lagu dibandingkan dengan ketenaran lagu yang diciptakan, yang artinya lagu yang diciptakannya sangat diminati oleh masyarakat dan diputar atau diperdengarkan di berbagai tempat secara berulang-ulang. Jika suatu karya cipta di katakan adalah sebuah kekakayaan yang berkaitan dengan ekonomi, sebagian besar penggunaan lagu atau musik tersebut selalu disertakan dengan aktivitas ekonomi (Nainggolan, 2016). Seharusnya para pencipta lagu dapat menikmati kekayaan intelektualnya yang mana objek kekayaan intelektual (lagu/musik) tersebut begitu disenangi oleh masyarakat lain. Hak Kekayaan Intelektual adalah hak untuk menikmati secara ekonomis hasil dari suatu kreativitas intelektual, dimana objek yang diatur dalam HKI adalah karyakarya yang timbul atau lahir karena kemampuan intelektual manusia.

Adanya kesenjangan ekonomi yang di amati oleh penulis dari seorang pencipta yang apabila dibandingkan dengan ketenaran lagu ciptaanya dan banyaknya orang yang memutar dan menikmati hasil ciptaanya memancing penulis untuk melakukan penelitian dengan menggunakan pendekatan teori sistem hukum oleh Lawrence M Friedman yang didalamnya ada unsur substansi hukum, struktur hukum dan budaya hukum. Substansi hukum adalah produk hukum yang dihasilkan melalui peraturan yang ada, dalam hal ini undangundang nomor 18 tahun 2014 tentang hak cipta adalah substansi hukum yang terkait dengan hak cipta yang tentunya akan dikaitkan dengan eksistensi undang-undang hak cipta tersebut terhadap karya cipta para pencipta yang dipublikasikan atau didistribusikan melalui teknologi digital.
Dalam pasal 8 undang-undang nomor 18 tahun 2014 dirumuskan tentang istilah hak ekonomi adalah "Hak ekonomi merupakan hak eksklusif pencipta atau pemegang hak cipta untuk mendapatkan manfaat ekonomi atas ciptaannya". Dengan demikian segala bentuk pemanfaatan ataupun publikasi suatu karya cipta dari seseorang pencipta atau pemegang hak cipta haruslah dengan persetujuan dari pencipta dan pencipta atau pemegang hak cipta kemungkinan akan dapat manfaat ekonomi dari pengguna (user) dalam memanfaatkan hasil karya cipta dari pencipta tersebut.

Pasal 9 ayat (1) undang-undang nomor 18 tahun 2014 tentang hak cipta juga telah merumuskan tentang hak-hak dari pencipta apabila penggunaan manfaat dari karya cipta yaitu Pencipta atau pemegang hak cipta sebagaimana dimaksud dalam pasal 8 memiliki hak ekonomi untuk melakukan :

a. Penerbitan ciptaan;

b. Penggandaan ciptaan dalam segala bentuknya;

c. Penerjemahan ciptaan;

d. Pengadaptasian,

e. pengaransemenan atau pentransformasian ciptaan;

f. Pendistribusian ciptaan atau salinannya;

g. Pertunjukan ciptaan;

h. Pengumuman ciptaan;

i. Komunikasi ciptaan;

j. Penyewaan ciptaan.

Kemudian pasal 9 ayat (2) menegaskan "Setiap orang yang melaksanakan hak ekonomi sebagaimana dimaksud dalam ayat (1) wajib mendapatkan izin pencipta atau pemegang hak cipta". Mengacu pada pasalpasal diatas yang menerangkan tentang hakhak para pencipta atau pemegang hak cipta terhadap karya cipta mereka, maka segala bentuk aktivitas seperti pada pasal 9 ayat (1) diatas tidak dapat dilakukan kecuali telah mendapatkan izin dari pencipta lagu atau musik atau pemegang hak cipta. Dalam era digitalisasi saat ini, dimana dunia internet 
yang semakin canggih kemudian didukung oleh inovasi aplikasi pendukung yang semakin memberikan fasilitas yang makin menarik bagi masyarakat, antara lain adalah aplikasi Youtube, Facebook, instagram dan baru-baru ini aplikasi Tik-tok yang tidak kalah trendnya, sehingga memudahkan masyarakat dalam melakukan pelanggara hak cipta sesuai dengan pasal 9 ayat (1) Undang-undang nomor 18 tahun 2014 tentang hak cipta. Undang-undang negara kita telah memberikan rumusan normanorma hukum yang jelas karena dalam perspektif substansi hukumnya telah dirumuskan dengan baik sehingga jika ada pelanggaran terhadap hak cipta maka undangundang nasional telah dapat memberikan perlindungan terhadap mereka melalui undang-undang nomor 18 tahun 2014 tentang hak cipta.

Prakteknya ternyata pelanggaran terhadap hak cipta ini masih banyak kita dapati. Banyaknya masyarakat yang melakukan pelanggaran terhadap UUHC 2014 pasal 9 ayat (1) tersebut diantaranya adalah melakukan pertunjukan ciptaan melalui teknologi digital yang ada saat ini tanpa adanya izin pemanfaatan lagu dari pencipta atau pemegang hak cipta.

Struktur hukum adalah bagian dari institusional dalam hukum dan meliputi lembaga penegak hukum seperti Kepolisian, Kejaksaan, Pengadilan (Barda Nawawi Arief, 2018). Ketiga lembaga tersebut diatas adalah lembaga negara yang bertugas dan secara sah dapat melakukan tindakan-tindakan atas adanya suatu indikasi pelanggaran hukum terhadap hak cipta. Namun kelihatannya penegak hukum berjumlah memberikan suatu kejutan dalam hal hak cipta ini apalagi saat ini pelanggaran hak cipta terjadi dalam dunia yang disebut dengan dunia maya, yaitu pelanggaran hak cipta melalui aplikasiaplikasi yang disebutkan diatas dengan bantuan jaringan internetnya. Penegakan hukum dalam dunia hak cipta ini dari zaman recording dengan wadah fisik yaitu $\mathrm{CD}, \mathrm{VCD}$ dan kaset, belum dapat melegakan para insan seni karena ketidak tegasan penegak hukum dalam melakukan tindakan kepada para pelanggar hak cipta ini.

Dahulu kala penindakan terhadap pelanggaran hak cipta hanya dilakukan terhadap para penjual $\mathrm{CD}, \mathrm{VCD}$ atau kaset bajakan kecil-kecilan, sementara pemain besar dalam pelanggaran hak cipta ini jarang sekali ditindak, hal ini dapat kita lihat dengan secara terang-terangan penjualan $\mathrm{CD}, \mathrm{VCD}$ bajakan yang dapat di temui dalam pusat perdagangan elektronik di salah satu daerah perdagangan besar Jakarta. Pasar Glodok dikenal sebagai salah satu pusat elektronik, tapi ada juga yang menyebutkan di sana adalah penjualan DVD atau VCD bajakan terbesar se Asia Tenggara.

Dengan melihat kenyatan yang ada di lapangan, penindakan oleh penegak hukum yang tidak maksimal dengan barang bukti CD atau VCD bajakan yang secara terangterangan digelar di pusat perdagangan tersebut tidak dapat dilakukan oleh penegak hukum, maka para insan seni, pencipta atau pemegang hak cipta dan seluruh seniman lagu maupun musik sangat pesimis terhadap penegakan pelanggaran hukum hak cipta ini dalam yang dilakukan dalam dunia era digital ini.

Hal ketiga sebagai unsur dari sistem hukum yang dicetuskan oleh Lawrence $M$. Friedman adalah tentang budaya hukum. Budaya hukum adalah suatu unsur yang dapat dijadikan sebagai objek analisa terhadap perlindungan hak cipta (Rawi, 2019). Budaya hukum adalah suatu istilah yang digunakan dalam menjelaskan hubungan perilaku sosial antar masyarakat dalam hubungannya dengan hukum. Budaya hukum adalah sikap manusia terhadap hukum, termasuk didalamnya nilai, pemikiran dan harapannya. Perilaku sosial masyarakat sangat berpengaruh terhadap eksistensi pelindungan hukum hak cipta bahkan norma-norma hukum lainnya. Perilaku sebagian masyarakat yang tidak peka dengan kekayaan intelektual sebagai kekayaan yang bernilai ekonomis terhadap para penciptanya 
atau kepada pemegang hak cipta sehingga dengan mudah dan tanpa adanya beban moral dan etika melakukan tindakan pelanggaran hukum hak cipta sebagaimana tercantum dalam pasal 9 ayat (1) UUHC 2014. Pelanggaran ini telah dilakukan di Indonesia dengan minimnya penindakan oleh aparat penegak hukum sehingga membuat budaya ini terpelihara hingga saat ini. Pada tahun 2009, Indonesia pernah dimasukkan dalam daftar negara sebagai pelanggar hak kekayaan intelektual dan diberi status sebagai negara dalam kategori Priority Watch List atau daftar negara yang menjadi prioritas untuk diawasi. Kemudian berkembangnya suatu pendapat dalam masyarakat dimana masyarakat berpendapat bahwa suatu hasil karya cipta dalam hal ini lagu atau musik setelah diumumkan oleh penciptanya, dapat diperdengarkan dan dipertunjukkan dimanamana dimana dalam aktivitas tersebut terdapat unsur ekonominya.

Lain lagi budaya yang timbul saat ini yaitu budaya dalam era teknologi digital atau era komputer dan internet. Budaya yang terbentuk dalam era digital dan era internet ini adalah dengan adanya rangsangan untuk membuat konten video yang menarik yang apabila mendapatkan pengunjung (viewers) yang banyak dan jam tayang konten yang banyak, maka pihak pengelola aplikasi akan memberikan apresiasi melalui pemberian materi, hal ini jugalah yang memacu pelanggaran hak cipta yang terjadi saat ini dalam era digital ini dimana masyarakat berlomba-lomba membuat berbagai macam bentuk konten termasuk didalamnya adalah masyarakat yang menambah jumlah kontennya dengan melakukan pertunjukan ciptaan, penerbitan ciptaan dan lain sebagainya.

\section{Kesimpulan}

Secara khusus pelindungan yang dibutuhkan oleh para insan seni dan dalam dunia industri musik ini adalah pelindungan terhadap hak ekonomi dan pelindungan terhadap hak moral. Adanya kesenjangan ekonomi yang terlihat didunia industri musik ini terhadap para pencipta lagu sebagai pemegang hak cipta lagu dibandingkan dengan ketenaran lagu yang diciptakan, yang artinya lagu yang diciptakannya sangat diminati oleh masyarakat dan diputar atau diperdengarkan di berbagai tempat secara berulang-ulang. Jika suatu karya cipta di katakan adalah sebuah kekayaan yang berkaitan dengan ekonomi, sebagian besar penggunaan lagu atau musik tersebut selalu disertakan dengan aktivitas ekonomi (Nainggolan, 2016). Seharusnya para pencipta lagu dapat menikmati kekayaan intelektualnya yang mana objek kekayaan intelektual (lagu/musik) tersebut begitu disenangi oleh masyarakat lain. Hak Kekayaan Intelektual adalah hak untuk menikmati secara ekonomis hasil dari suatu kreativitas intelektual, dimana objek yang diatur dalam HKI adalah karyakarya yang timbul atau lahir karena kemampuan intelektual manusia.

\section{BIBLIOGRAFI}

Ahmad Tamamy. (2009). Kemajuan Elektronik Untuk Kebutuhan Komunikasi (MEDIA CETAK). https://semutmanis.wordpress.com/2009/ 10/13/kemajuan-elektronik-untukkebutuhan-komunikasi-media-cetak/

Anshori, A. G. (2018). Filsafat hukum. Ugm Press.Google Scholar

Barda Nawawi Arief, S. H. (2018). Masalah penegakan hukum dan kebijakan hukum pidana dalam penanggulangan kejahatan. Prenada Media. Google Scholar

Besar, B. (2012). Pengalihwujudan dalam Kerangka Konsep Hukum Hak Cipta. Humaniora, 3(1), 10-22. Google Scholar

Damian, E. (1999). Hukum hak cipta menurut beberapa konvensi internasional, 
Undang-Undang Hak Cipta 1997 dan perlindunganya terhadap buku serta perjanjian penerbitannya. Penerbit Alumni. Google Scholar

Dewatara, G. W., \& Agustin, S. M. (2019). Pemasaran Musik pada Era Digital Digitalisasi Industri Musik dalam Industri 4.0 di Indonesia. WACANA: Jurnal Ilmiah Ilmu Komunikasi, 18(1), 1-10. Google Scholar

Fonna, N. (2019). Pengembangan Revolusi Industri 4.0 dalam Berbagai Bidang. Guepedia. Google Scholar

Hanifannur, M. (2021). Perlindungan Hukum Terhadap Hak Cipta Uploader Youtube Dalam Pasal 40 No. 28 Tahun 2014 Tentang Hak Cipta Perspektif Hukum Islam. Google Scholar

Kariodimedjo, D. W. (2010). Perlindungan Hak Cipta, Hak Terkait, dan Desain Industri. Jurnal Mimbar Hukum, 22(2), 265-282. Google Scholar

Nainggolan, B. (2016). Komentar UndangUndang Hak Cipta. Alumni. Google Scholar
Rawi, H. E. (2019). Sertifikasi wakaf tanah milik perspektif teori sistem Hukum Lawrence M. Friedman: Studi di Desa Jeruk Soksok, Kecamatan Binakal, Kabupaten Bondowoso. Universitas Islam Negeri Maulana Malik Ibrahim. Google Scholar

Republik Indonesia. (2014). Undang-undang Nomor 28 tahun 2014 tentang Hak Cipta.

https://peraturan.bpk.go.id/Home/Details /38690

Salindeho, C. C. (2017). Perlindungan Musik Dan Lagu Di Era Teknologi Internet Dalam Perspektif Undang-Undang Hak Cipta Indonesia. Lex et Societatis, 5(5). Google Scholar

Utsman, S. (2014). Metodologi penelitian hukum progresif: pengembaraan permasalahan penelitian hukum aplikasi mudah membuat proposal penelitian hukum. Pustaka Pelajar. Google Scholar

Wibawa, D., \& Krisnawati, I. (2019). Upaya Mediasi Dalam Penyelesaian Sengketa Pelanggaran Hak Cipta. Jurnal Kertha Wicara, Fakultas Hukum Universitas Udayana, 8(01). Google Scholar

\section{Copyright holder :}

Surung B Simanjuntak, Bernard Nainggolan, Hendri Jayadi (2022)

First publication right :

Jurnal Syntax Transformation

This article is licensed under:

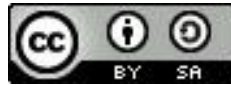

